\title{
Szôlôterületek eróziójának térbeli modellezése a Neszmélyi borvidéken felszínközeli távérzékelés segítségével
}

\author{
TAKÁTS Tünde - ALBERT Gáspár
}

DOI: $10.30921 / G K .73 .2021 .6 .3$

Absztrakt: A kutatás során három szôlôterület egyéves megfigyelése zajlott 2019 júliusa és 2020 júniusa között a Gerecse északi részén található Neszmélyi borvidéken. A területekrôl minden évszakban pilóta nélküli repülōgépröl készültek fényképsorozatok. A felvételek fotogrammetriai feldolgozásával nagy felbontású digitális terepmodelleket állitottunk elö, melyeket a talajerózió becslése során használtunk fel. A talajerózió mértékének meghatározásához az általános talajveszteség-becslési egyenletet (USLE) alkalmaztuk. A becslés során különös figyelmet kapott az évszakonként változó növényboritottság, illetve csapadékmennyiség hatása. A gazdálkodás során a szölészet által használt eróziócsökkentố lépések egyikének, a sorok közötti gyepesítésnek a hatékonyságát is vizsgáltuk. A talajveszteségre vonatkozó kvantitatív eredmények alapján számszerúsítettük, hogy a nyári intenzív esózések mennyivel jelentôsebb eróziót váltanak ki, mint az ôszi vagy téli csapadék.

Abstract: In this study, three vineyards in the Neszmély Wine Region, northern part of the Gerecse Hills were investigated. The one-year monitoring of vineyards began in July 2019. A series of photographs were taken of the vineyards from an unmanned aerial vehicle in all seasons. The images were used for photogrammetric analysis to produce highresolution digital terrain models (DTMs) and orthophotos. The USLE (Universal Soil Loss Equation) model was used to determine the extent of soil erosion. During the estimation, particular attention was paid to the effect of seasonal variation in vegetation cover and rainfall. We also modelled the erosion control effect of the inter-row grassing that is already used by the vineyards. The results confirm and quantify that intense summer rainfall has a more significant effect on erosion compared to autumn or winter rainfall.

Kulcsszavak: szőlőültetvények, talajerózió, UAV, USLE

Keywords: vineyards, soil erosion, UAV, USLE

\section{Bevezetés}

A talajerózió természetes folyamatát az emberi tevékenység erôteljesen befolyásolja a mezőgazdasági területeken. Degradációról akkor beszélünk, amikor a talajképzôdés már nem képes lépést tartani az emberi tevékenység által felgyorsított talajpusztulás mértékével (Stefanovits 1992). A talajerózió vizsgálata napjainkban is fontos kutatási téma nem csak nemzetközi, de hazai szinten is (Waltner et al. 2018, 2020; Dezső et al. 2020).

Az erózió elleni védekezés módja a kiváltó tényezók hatásának csökkentése, illetve a módosító tényezôk pusztulást csökkentô befolyásolása (Stefanovits 1992). Számos módszer ismert a talajpusztulás mértékének csökkentésére:

- a lejtô tagolása vagy a teraszolás

- múvelési ág változtatása

- a lejtôirányra meróleges táblásítás

- a megfelelố talajmúvelési módok alkalmazása

- talajvédó fasorok kialakítása (Szendrei 1998).
A szôlészetben gyakran alkalmazott módszer a sorközök gyepesítése, ami lehet állandó vagy idôszakos. A tartós gyepesítés alkalmazható az összes vagy minden második sorközben, továbbá minôségét tekintve lehet vetett gyep vagy természetes gyomflórával meghagyott. Mivel a gyep növényzete is vizet igényel, ezért általában ezt a módszert akkor ajánlják, ha a területen az évi csapadék mennyiség meghaladja a 600-800 mm-t, ebben az esetben nem jelent konkurenciát a szôlő számára. Nem kizárólag a csapadék mennyiség határozza meg a módszer alkalmazhatóságát, hanem a lejtésviszonyok is. A mintaterületeken az utóbbinak van nagyobb szerepe.

A Gerecse területén napjainkban is több felszínfejlốdési vizsgálat zajlik, amelyek kimutatták, hogy mind a talajerózió, mind pedig a csuszamlás mértéke jelentôs (pl.: Schweitzer 1989, Albert 2013, Kis-Balogh 2013 , Ruszkiczay-Rüdiger et al. 2016, Gerzsenyi-Albert 2017, Takáts 2018, Gerzsenyi-Albert 2021). A vizsgált területen található hazánk egyik ismert borvidéke, a Neszmélyi borvidék. Ennek a borvidéknek az egyik jelentôs szôlőbirtoka és borászata a Hilltop Neszmély Zrt., amelynek a területén több ültetvény is az erózió által veszélyeztetett (Takáts 2020).

A talajerózió mértékének kiterjedtebb térbeli becslését múholdas távérzékelési adatok és meteorológiai mérések felhasználásával, valamint a terület talajtani ismeretében térinformatikai módszerek segítségével oldják meg (Waltner et al. 2020). Ezeket az eljárásokat sikerrel alkalmazták felszínközeli távérzékelési adatokkal is, amelyek nagy felbontású (pár cm/pixel) modellek előállítására is alkalmasak (Pijl et al. 2020, Waltner 2018). Utóbbi módszer értelemszerúen kisebb, de szintén összefüggố területre vonatkozóan alkalmazható. Fernandez és munkatársai (2020) Spanyolországban vizsgálták eróziós barázdák kialakulását olajfaültetvényeken, Pijl és munkatársai (2020) pedig Észak-olaszországi szôlôterületeken alkalmazták ezt az eszközt talajerózió becslésére. Kanadában hasonló modellezéseket 
mezôgazdasági területeken végeztek (Meinen-Robinson 2021). Nepálban teraszos múvelés erózióvizsgálata során használtak fel felszínközeli távérzékelésből származó adatokat (Chidi et al. 2021). Az itt említett kutatásokban különféle eróziós modelleket alkalmaztak szubméteres felbontásban pl: USLE, RUSLE (Revised Universal Soil Loss Equation), SIMWE (SIMulated Water Erosion).

Jelen kutatás során kiemelten erózióveszélyes szôlốmúvelési területek rövid és középtávú megfigyelését végeztük el, melynek révén évszakonként nagy felbontású $(10 \mathrm{~cm} /$ pixel $)$ talajpusztulási térképeket készítettünk a mintaterületekrôl, melyek segítségével a térben megbecsültük az egyes területeken a talajpusztulás mértékét és változásának dinamikáját az év során.

\section{Anyag és módszer}

\subsection{A mintaterületek}

A mintaterületek a Neszmélyi borvidéken, Dunaszentmiklós környékén, a Hilltop szőlészet területén találhatók (1. ábra). Az elsố terepbejárásra 2019 júliusában került sor. A szőlészet munkatársai érdeklôdve fogadták a kutatási témát, és segítségünkre voltak a mintaterületek kiválasztásában. Elmondták, hogy mely területeken okoz számukra problémát a nagymértékú és gyors talajpusztulás. Ezeket az információkat összevetettük a Térképtudományi és Geoinformatikai Intézetben folyó korábbi közepes léptékú alapadatokkal végzett eróziós és csuszamlásvizsgálatok eredményeivel (Gerzsenyi-Albert 2017, Takáts 2018, Gerzsenyi-Albert 2021). Végül a vizsgálat során összesen 63,4 hektáron, három mintaterületen végeztünk talajerózió-becslést, melyeken a közepes léptékű modellek és a helyi tapasztalatok szerint is nagymértékú a talajpusztulás.

A területek elnevezései a dûlố nevekból származnak, valamint a szôlészet által használt táblanevekbôl (3. ábra). 1. terület Elô-haraszt, 2. terület Kereszt-rét, 3. terület Göteoldal és Korma föle. A késôbbiekben a sorszámuk alapján történik rájuk a hivatkozás.

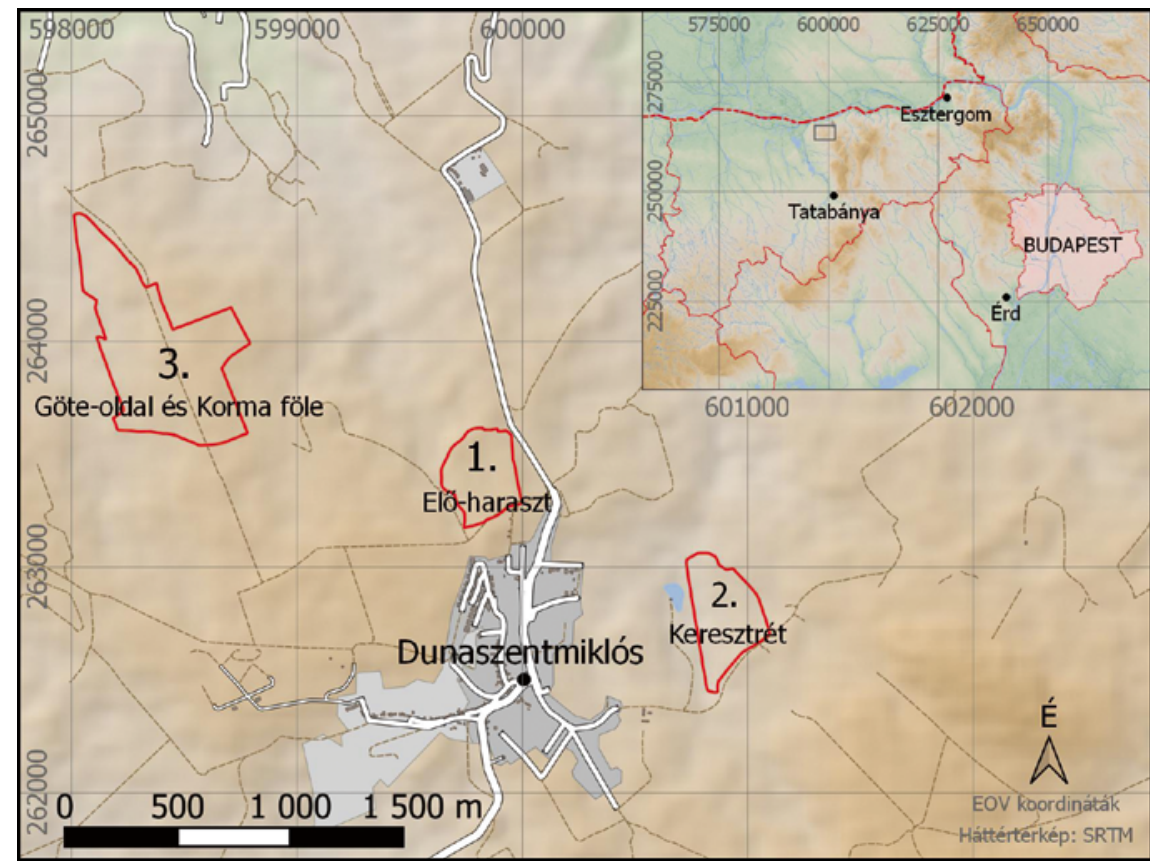

1. ábra. Áttekintô térkép a mintaterületek (számokkal jelölt) tágabb és szükebb környezetérôl.
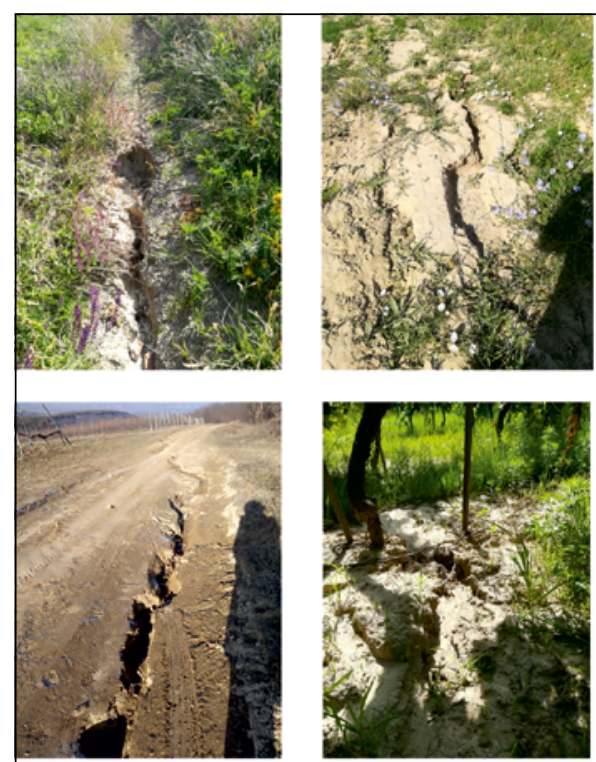

Vízmosások
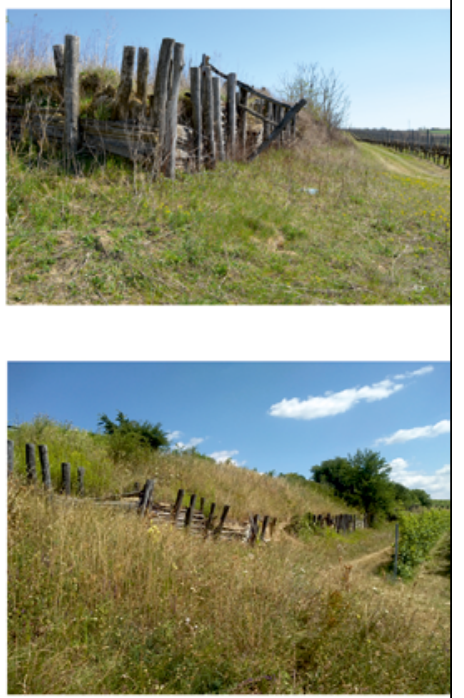

Teraszos rész

2. ábra. Eróziós nyomok a 3. területen

$\mathrm{Az}$ 1. területen, az Elő-haraszt azon része került a figyelem középpontjába, ahol 2018-ban telepítettek fiatal tôkéket. Ezért ezen a területen még kis méretúek a tôkék, így itt megfigyelhetô, hogy mi történik a fedetlen talajjal. Az 1. terület keleti és nyugati részén szántó található. A 2. területet egy nagyobb vízmosás szeli át, és a tôkkesorok között begyepesítették a talajt. A 3. terület esetében változatos a talajfelszín. Vannak olyan parcellák, ahol a tôkesorok köze gyepesített, máshol pedig nem. Ezen a területen több vízmosás is megfigyelhető (2. ábra"). A terület egy kiemelten veszélyes részén három terasz található, ahol a szőlooket nem tudják géppel múvelni, mert félnek, hogy megindul a föld a munkagépek alatt (2. ábra). A szólootookkehiány mértéke a Teraszos parcellában a legnagyobb. A Csücsök elnevezésú parcellában (3. ábra) 2019 ősszén szedték ki a tôkéket, és 2020 tavaszán telepítették újra. A szôlészet több intézkedéssel is igyekszik lassítani a talajerózió mértékét. Az egyik védekezési mód, 


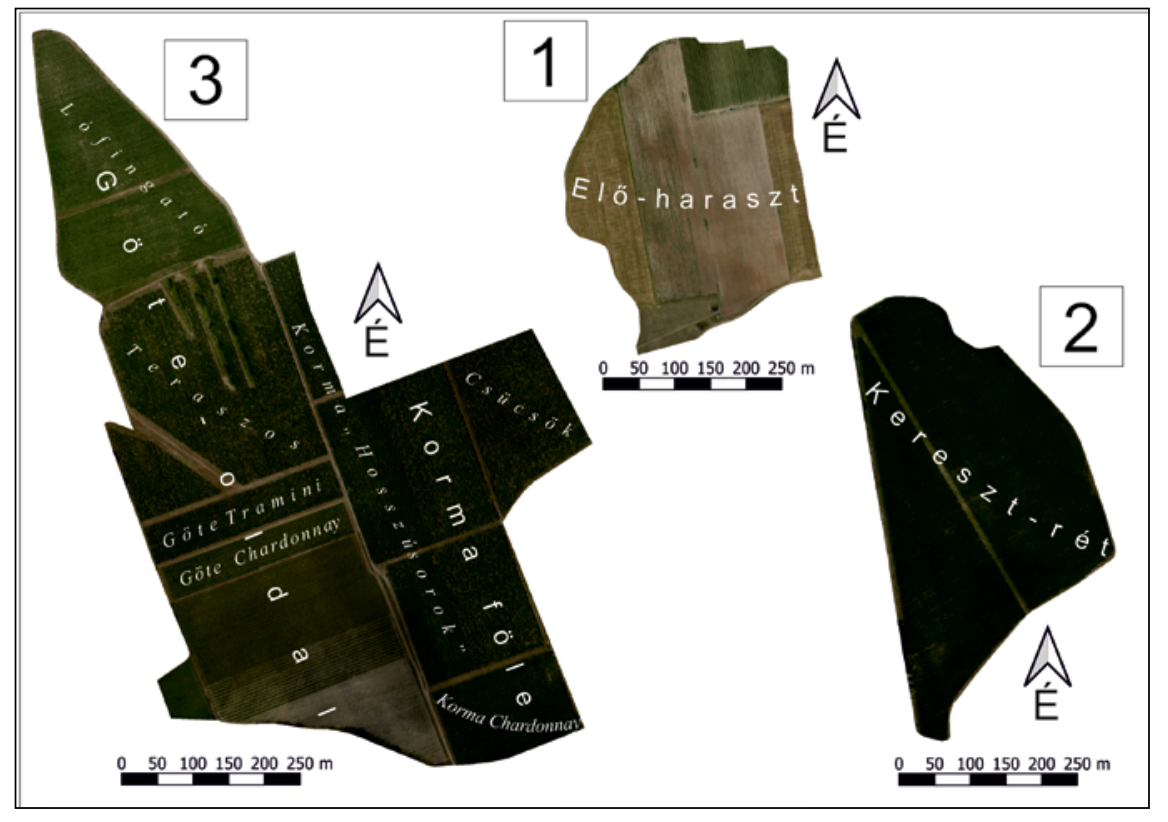

3. ábra. A mintaterületeken (számokkal jelölt) található parcellák.

hogy 2017 óta a szôlôsorok között állandóan gyepesítenek. A kezelők megfigyelése szerint, azóta szemmel láthatóan kisebb mértékú a talajerózió.

\subsection{A légi felmérések}

A projekt egy egész évet átölelô megfigyeléssorozatra épül, amelynek során minden évszakban drónfelvételek készültek a mintaterületekrôl. A terepi mérések idôpontjait, idôjárásviszonyait és a mérések sikerességét a 1. táblázat mutatja be. A felmérések során három különbözô típusú UAV-eszközt használtunk. Az elsố két alkalommal egy házilag fejlesztett drónra szerelt Ricoh GR II kompakt fényképezógép segítségével készültek a felvételek. Az eszközhöz tartozott egy RTK (Real-Time Kinetic) GPS-vevô, mely a nagy pontosságú helymeghatározást biztosította. A repülések megkezdése elôtt egy bázisállomást helyeztünk el a szôlészet telephelyén, mely a korrekciós adatokat szolgáltatta. A feldolgozás során az elsô, azaz a 2019. nyári

1. táblázat. A terepi mérések adatai és fényképek a mintaterületekrôl.

\begin{tabular}{|c|c|c|c|}
\hline & Idốpont & Idôjárás & Sikeresség \\
\hline Terepbejárás & 2019.07 .05$. & meleg, napos idő & $\checkmark$ \\
\hline Nyári mérés & 2019.07 .24$. & meleg, napos idố & $\checkmark$ \\
\hline Ószi mérés & 2019. 11.14. & tavaszias meleg, napos idô & $\checkmark$ \\
\hline \multirow[t]{3}{*}{ Téli mérés } & 2020.01 .24$. & húvös, napos, erôsen szeles idő & $x$ \\
\hline & 2020.01 .25 & hû́vös, ködös idő & $x$ \\
\hline & 2020.02 .19$. & húvös, enyhén szeles, napos idő & $\checkmark$ \\
\hline
\end{tabular}

repülési információkkal (sebesség, magasság stb.) együtt lehetett követni az UAV-eszközt.

\subsection{Az adatok feldolgozása}

Az elkészült drónfelvételekből fotogrammetriai módszerekkel ortofotó és felszín-, majd terepmodell készült (MetaShape, illetve Cloud Compare programok segítségével). A nyári mérés feldolgozása kis mértékben eltért a többitől. Ekkor a képekhez tartozó koordinátákat a drónra szerelt RTK GPS-ból nyertük ki, amelyek alapján a fotók elóbb a valós térbeli pozíciójukba kerültek, és ezt követôen történt a képek átfedéselemzése majd a térbeli pontfelhômodell előállítása SFM-elv (Structure From Motion) alapján. A sû́rû́ pontfelhố magasság szerinti kategorizálása alapján leválogathatók a talajpontok, azaz kiszúrhetô a növényzeti fedettség, és így előállítható a nagy felbontású digitális terepmodellt (DTM), valamit ennek geometriája alapján az ortofotó. A mintaterületek lehatárolásához egy-egy shape-fájlt alkalmaztunk következetesen minden évszakos felvételnél.

A késóbbi alkalmakkor az egyes képekhez nem mindig tartoztak megfelelő GPS-adatok, ezért a nyári felvételeken jól azonosítható (nem változó) objektumok alapján illesztôpontokat (Ground Control Points - GCP) határoztunk meg, amelyek adatait egy szöveges fájlban (txt) tároltunk. Az ôszi, téli és tavaszi képek térbeli illesztésekor ezeket a pontokat használtuk fel, bejelölve helyüket a felvételeken. Így a nyári méréshez igazított térbeli elhelyezkedését kaptuk meg a felvételeknek. A térbeli illesztést követôen a felszínmodellek pontfelhôje készült el, majd ezek után a feldolgozás menete már megegyezett a korábban ismertetekkel. Az elkészült terepmodelleket és ortofotókat $10 \mathrm{~cm} /$ pixel felbontásban exportáltuk.

Az eredményül kapott terepmodelleket a talajpusztulás becslése során a morfometriai tényezó és a talajmúvelési mód meghatározásánál használtuk. A DTM feldolgozása és a mintaterületek kezelése QGIS szoftverkörnyezetben történt. Az ortofotókat a növényborítottsági osztályok meghatározásánál alkalmaztuk. 


\subsection{Erózió becslése az általános talajveszteség- becslési egyenlettel}

Az elsôdleges cél az volt, hogy a kiemelten erózióveszélyes szólóterületekre olyan nagy felbontású talajpusztulási térképek készüljenek, melyek segítségével mérni lehet a talajerózió mértékének az egyes évszakok közti változását.

A talajveszteség területegységre vonatkozó mértékének meghatározásához az általános talajveszteség-becslési egyenletet (USLE) alkalmaztuk. Az egyenletet alkotó egyes tényezôk kifejezik azt, hogy az éghajlat, a talaj, a felszín morfológiája, a felszínborítottság, valamint az alkalmazott múvelési mód hogyan befolyásolják a talajpusztulás mértékét. Az egyenlet segítségével átlagbecslést lehet készíteni egy adott terület éves (vagy más meghatározott időszakra vonatkozó) talajpusztulására. Az egyenletet az Amerikai Egyesült Államokban dolgozták ki az 1940-es években (Wischmeier-Smith 1978). Kezdetben angolszász mértékegységeket használt a módszer, majd 1981ben elkészült az egyenlet SI (Systeme International d'Unites - Nemzetközi Mértékegységrendszer) változata is (Foster et al. 1981). Azóta igen elterjedt az egyenlet, vagy annak továbbfejlesztett változatai a talajpusztulás becslésére (Fantappiè et al. 2014, Odongo et al. 2013, Lahloi et al. 2015, Confortiet al. 2015). Az egyenlet hat térbeli változót tartalmaz, amelyek szorzataként áll elô az időegységre (a képletben év) vonatkoztatott talajerózió mértéke:

$A=R \cdot K \cdot L \cdot S \cdot C \cdot P$

$\mathrm{A}=$ az évi átlagos talajveszteség

$$
\left[\frac{t}{h a \cdot e ́ v}\right]
$$

$\mathbf{R}$ = a csapadék eróziós potenciálja

$$
\left[\frac{M J \cdot m m}{h a \cdot b \cdot e ́ v}\right]
$$

$\mathrm{K}=\mathbf{a}$ talaj erodálhatósági tényezôje

$$
\left[\frac{t \cdot h a \cdot b}{h a \cdot M J \cdot m m}\right]
$$

$\mathrm{L}=$ a lejtô hosszát kifejezô tényezô (dimenzió nélküli)

$\mathrm{S}=$ a lejtố meredekségét kifejezô tényező (dimenzió nélküli)

$\mathrm{C}=\mathrm{a}$ növényi fedettség tényezője (dimenzió nélküli)

$\mathrm{P}=$ az alkalmazott talajmúvelési mód tényezője (dimenzió nélküli)
Jelen kutatásban az A értéke az egyes évszakokra vonatkozik, így a csapadékadatokat a nyári (júniustól-augusztusig), az ôszi (szeptembertôl-novemberig), a téli (decembertôl-februárig) és a tavaszi (márciustól-májusig) idôintervallumokra vettük figyelembe. A nagy felbontású DTM-nek köszönhetôen a területegység mérete is kisebb $(10 \times 10 \mathrm{~cm})$, ezért az erodált talaj menynyiségét is kisebb súlymérték érzékelteti megfelelôen. A talajerózió (A), az eróziós potenciál (R) és az erodálhatósági tényezô (K) így a következô módon alakult:

$\mathrm{A}=\mathrm{az}$ évszakonként átlagos talajveszteség

$$
\begin{array}{r}
{\left[\frac{k g}{d m^{2} \cdot e ́ v s z a k}\right]} \\
\mathrm{R}=\text { a csapadék eróziós potenciálja } \\
{\left[\frac{M J \cdot m m}{d m^{2} \cdot b \cdot e ́ v s z a k}\right]} \\
\mathrm{K}=\text { a talaj erodálhatósági tényezôje } \\
{\left[\frac{\mathrm{kg} \cdot d m^{2} \cdot h}{d m^{2} \cdot M J \cdot m m}\right]}
\end{array}
$$

\subsubsection{R-faktor}

A talajpusztulás függ a csapadék intenzitásától és az esôcseppek nagyságától. Az R-faktor az esó kinetikus energiáját fejezi ki, amely. tartalmazza az egyes csapadékesemények eróziós indexét, valamint a lefolyásuk anyagmozgató képességét. Az $\mathrm{R}$ tényezô értékét $\left[\frac{M J \cdot m m}{h a \cdot b}\right]$-ban adják meg

(Wischmeier-Smith 1978).

Az R-faktor kiszámításához az óránkénti csapadékadatokat az Országos Meteorológiai Szolgálat (OMSZ) biztosította. Két mérôállomás adatai álltak rendelkezésünkre: 1) Gerecsetetố és 2) Tata, Új út. A Gerecse tetôn 581,6 mm, míg a Tata, Új út állomásnál 471,4 mm csapadékot mértek az egy év során.

Az eróziós egyenlethez szükséges volt a lehullott csapadék havi összesített mennyiségét és az R-faktor értékét (4. ábra) kiszámítani. Az adatokból leolvasható, hogy mikor volt jellemzó a hosszabb ideig tartó gyenge esôzés és mikor a hirtelen lezúduló nagy menynyiségú, de rövid idegig tartó esôzés. Az erózióbecslés során az R-faktor értékeket évszakonként összegezve használtuk fel.

A legcsapadékosabb hónapok a június, a november és a december voltak. A havi R értékekbôl kiderül, hogy júniusban sokkal nagyobb hatással volt az esőzés a talajerózióra, mint novemberben vagy decemberben. Ennek az az oka, hogy novemberben és decemberben hosszabb ideig tartó lassú esôzések voltak, míg június 22-én az esti órákban bekövetkezett egy hirtelen lezúduló, nagy mennyiségú csapadékesemény.

Az egy évszakon belüli, azaz három hónapos eróziós indexek összegzésével kaptuk az évszakos R-faktort, amit a talajerózió becslése során használtunk fel (2. táblázat).

2. táblázat Az évszakos $R$ értékek.

\begin{tabular}{|c|c|}
\hline Évszak & {$\left[\begin{array}{c}\text { R-faktor } \\
\text { hJ } \boldsymbol{h} \cdot \boldsymbol{b} \cdot \boldsymbol{b} \cdot \hat{v} \mathbf{s z a k}\end{array}\right]$} \\
\hline Nyár & 351,59 \\
\hline Ốsz & 27,19 \\
\hline Tél & 26,22 \\
\hline Tavasz & 27,02 \\
\hline
\end{tabular}

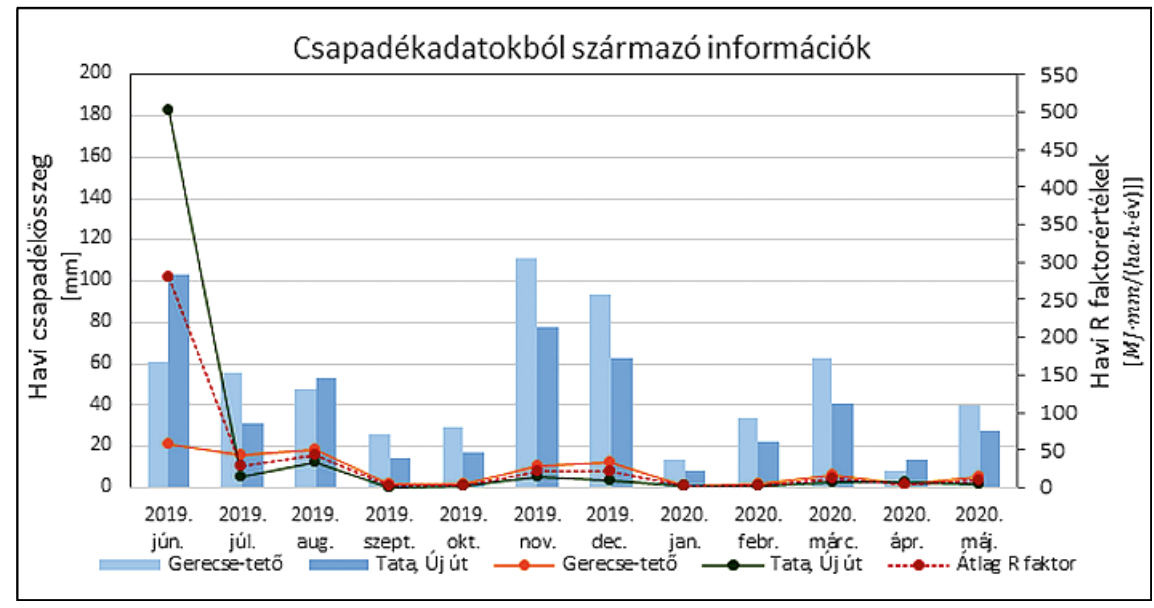

4. ábra. A két mérốállomás csapadék adatokból származtatott információk: havi csapadékösszeg és a havi R-faktorértékek. 


\subsubsection{K-faktor}

A K tényezố megmutatja, hogy egy adott talaj mennyire hajlamos az erózióra, egyszóval: a talaj erodálhatóságát, amelyet a talaj több tulajdonsága is befolyásol pl.: a talaj szerkezete, a talajban található szemcsék összetétele, a talaj vízáteresztő képessége, a szervesanyag- és agyagásvány-tartalma (Wischmeier-Smith 1978). Ezen elsődleges talajjellemzők alapján becsülhető $\mathrm{K}$ értéke, melynek Pásztor és munkatársai (2016) által szerkesztett egyhektáros felbontású térképi állományát használtuk jelen vizsgálatunk során. A mintaterületre vonatkozó K-faktorértékek a következó intervallumokban estek (3. táblázat):

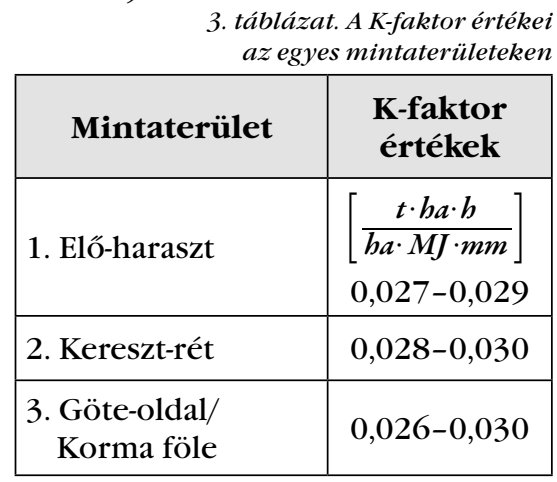

\subsubsection{LS-faktor}

Az USLE-egyenlet morfometriai eleme az LS-faktor. Ez két tényezóbôl tevốdik össze, az L a lejtôhossz (slope length), és az $\mathrm{S}$ meredekség (steepness) változóból, melyek szorosan összefüggnek egymással, ezért szokás ôket egybevontan LS-faktornak nevezni. Ez a faktor megmutatja, hogy a felszín egyenlőtlenségei mekkora hatással vannak a talajerózió mértékére.

Az LS-faktort GIS-eszközökkel az egységre vonatkoztatott terület (unit contributing area - UCA) elve alapján digitális terepmodellből lehet kiszámítani (pl. Brychta-Brychtová 2020). A drónfelvételból elôállított, nagy felbontású DTM-ből levezetett lejtômeredekség és lefolyásakkumuláció cellákra vonatkoztatott értékeinek felhasználásával állítottuk elő az L és a S értékeket. Az L-faktor számítása (Wischmeier-Smith 1978) alapján történt:

$$
\begin{aligned}
& \quad L=\left(\frac{\lambda}{22,13}\right)^{m} \\
& \lambda=\text { a lefolyásakkumuláció. }
\end{aligned}
$$

Az egyenletben szerepelô $m$ hatványkitevô egy konstans érték, amely a lejtô százalékban megadott mértékétôl függ (Presbitero 2013).

$m=0.5, s>5 \% ; \quad m=0.4,3<s \leq 5 \%$ $m=0.3, \quad 1<s \leq 3 \% ; \quad m=0.2, \quad s \leq 1 \%$

Az S-faktor kiszámítása szintén Wischmeier-Smith egyenlete (1978) alapján történt:

$S=65.41 \cdot \sin ^{2} \theta+4.56 \cdot \sin \theta+0.065$

$\theta=$ lejtô meredeksége (radiánban).

Minden egyes idôszakra elkészültek a mintaterületek lefolyásakkumulációs térképei és a lejtôszögtérképei, amelyek segítségével meghatározható volt az L- és az S-faktor is. A két faktort raszteres adatként felhasználva, azok cellánkénti összeszorozásával készültek el az LS-térképek.

Az elkészült térképek alapján kirajzolódnak a nagyobb vízfolyások és azok hatása a talajpusztulás mértékére. Az egyes évszakok közötti különbség is megfigyelhető, melynek egyik fő oka a morfológia változása, a lehullott csapadék, illetve a területeken folyó mezôgazdasági munkák hatása.

\subsubsection{C-faktor}

A C-faktor megmutatja, hogy a talajfedettségnek és a talajhasználatnak mekkora szerepe van a talajerózió mértékében. Ez a tényezố mind idôben mind pedig térben igen változatos lehet, és mivel a növényfedettségnek jelentôs szerepe van a talajerózió mérséklésében, a C-értékek különbözô sûrûségú és típusú növényborítottságra lettek meghatározva (4. táblázat). A különbözô felszínborítások C értéke akár nagyságrendekkel is különbözhetnek egymástól, de 0 és 1 közé kell esniük (Panagos et al. 2015). Minél sûrúbb és nagyobb kiterjedésû́ a növénytakaró, annál jobban lassítja az eróziót. Ennek oka, hogy a növények gyökerei megkötik a talajt, valamint a levelek felfogják a lehulló csapadékot, ezáltal csökkentik a többi tényezô hatását is.
A C-faktor meghatározásához az évszakonként készített ortofotókat használtuk. Mivel általában csak három különbözô kategóriát kellett elkülöníteni (szôlôs, füves terület, csupasz talaj), így jól múködött a látható színek (RGB-sávok) szerinti irányított osztályozás, amely a Minimum Distance módszert követte. Az osztályozott képeken kimutatható az évszakos fedettségváltozás mind a szólő, mind pedig a füves területek vonatkozásában.

4. táblázat. C-faktorértékek a különbözố fedettség típusokra (Panagos et al. 2015)

\begin{tabular}{|l|c|}
\hline Fedettség típus & C-faktorérték \\
\hline Csupasz talaj & 1 \\
\hline Szőlő & 0,3605 \\
\hline $\begin{array}{l}\text { Mezőgazdasági } \\
\text { terület }\end{array}$ & 0,1491 \\
\hline Füves terület & 0,0564 \\
\hline $\begin{array}{l}\text { Átmeneti fás, } \\
\text { bokros }\end{array}$ & 0,0306 \\
\hline Köves, sziklás & 0 \\
\hline
\end{tabular}

\subsubsection{P-faktor}

Ez a változó megmutatja, hogy az alkalmazott talajmúvelési mód hogyan befolyásolja a talajerózió mértékét. Ez azt jelenti, hogy milyen arányban van jelen a területen a vízszintes, sávos vagy teraszos múvelés a lejtô irányú múveléshez képest (Wischmeier-Smith 1978).

A többi faktor nagy felbontásának köszönhetôen a P-faktor meghatározását is próbáltuk minél pontosabban elvégezni. A P-faktor számértékeit Fehér és munkatársai (1986) alapján származtattuk (5. táblázat). A vizsgált szőlőterületeken elsősorban a vízszintes sávos múvelés fordult elô, de néhol a lejtőirányú múvelés is megjelent. A mintaterületeken az egyéb mezőgazdasági területek esetében alkalmazták a vízszintes múvelést. Azokon a területeken, ahol nem tudtuk pontosan meghatározni és/vagy nem történik múvelés a P-faktor 1-es értéket kapott, azaz nem volt eróziócsökkentố szerepe.

5. táblázat. A P-faktor számértékei müvelési típus és lejtôszög alapján (Fehér-Horváth-Ondruss 1986).

\begin{tabular}{|c|c|c|c|}
\hline Lejtô \% & $\begin{array}{c}\text { Lejtôirányú } \\
\text { múvelés }\end{array}$ & $\begin{array}{c}\text { Vízszintes } \\
\text { múvelés }\end{array}$ & $\begin{array}{c}\text { Vízszintes sávos } \\
\text { múvelés }\end{array}$ \\
\hline $1,1-2,0$ & 1 & 0,60 & 0,30 \\
\hline $2,1-7,0$ & 1 & 0,50 & 0,25 \\
\hline $7,1-12,0$ & 1 & 0,60 & 0,30 \\
\hline $12,1-18,0$ & 1 & 0,60 & 0,40 \\
\hline $18,1-24,0$ & 1 & 0,90 & 0,45 \\
\hline
\end{tabular}




\subsection{A talajfedés}

\section{hatásának vizsgálata}

A talajfedés eróziócsökkentő hatását vizsgáló forgatókönyvben a 2 . és a 3. terület kapta a nagyobb figyelmet. Ennek kiszámítása során azt vizsgáltuk, hogy ezeken a területeken mekkora a gyepesítés jelentôsége a talajpusztulás szempontjából.

Ehhez a forgatókönyvhöz készítettünk egy új C-faktor-térképet, amelyen az addig füves területeket felváltja a csupasz talaj, azaz a C-érték 0,0564rôl 1-re nôtt. A 6. táblázat tartalmazza a mintaterületek teljes méretét és a területén található gyep nagyságát, amely a C-faktor modellezése során változott. A modellezett C-faktorral is megbecsültük a talajerózió mértékét.

\section{Eredmények és diszkusszió}

\subsection{Az éves talajpusztulás alakulása}

Mind a négy idôszakra elkészültek a becsült talajpusztulási térképek az egyes mintaterületekre (5. ábra). A térképek azt szemléltetik, hogy egy cellában, azaz egy dm²-en egy évszak alatt hány kg talaj erodálódik (7. táblázat).

A 7. táblázat bemutatja az egyes mintaterületek évszakonkénti talajpusztulását, illetve az egy $\mathrm{dm}^{2}$-re jutó átlagos talajpusztulás mértékét. Mind a négy mintaterületen a nyári idôszakban volt a legnagyobb a talajpusztulás mértéke annak ellenére, hogy ekkor a legnagyobb a növényborítottság az egyes területeken. Az átlagos erózió egy nagyságrenddel tért el az ôszi, a téli, illetve a tavaszi talajpusztulási értékektôl (nyáron: $6,8-16,39 \mathrm{~kg} /$ cella illetve télen: 0,9-1,81 kg/cella). Ennek oka a nyár folyamán lehulló, intenzív esô. A tavaszi mérés során egyedül a 2 . mintaterületen volt alacsonyabb a talajpusztulás mértéke az ôszi és a téli méréshez képest, de az eltérés mértéke nagyságrenden belüli. Az 1. és a 3. mintaterületek esetében ekkor volt a nyári után a legnagyobb az erózió ( 1,22 és $1,81 \mathrm{~kg}$ / cella), ez az ôszi és téli hónapokhoz képest kevesebb, de intenzívebb csapadéknak köszönhetô.

Magyarország területén $15 \mathrm{t} /($ ha év) a talajpusztulás maximálisan elfogadható mértéke Ez átszámítva az általunk

6. táblázat. A mintaterületek nagysága és a füves területek mérete ha-ban meghatározva

\begin{tabular}{|c|c|c|c|}
\hline Mintaterület & Évszak & $\begin{array}{l}\text { Teljes mintaterület } \\
\text { mérete (ha) }\end{array}$ & $\begin{array}{l}\text { Füves terület } \\
\text { mérete (ha) }\end{array}$ \\
\hline \multirow{4}{*}{ 1. Elő-haraszt } & 2019. nyár & \multirow{4}{*}{10,94} & 1,37 \\
\hline & 2019. ôsz & & 3,32 \\
\hline & 2019-2020. tél & & 2,48 \\
\hline & 2020. tavasz & & 1,49 \\
\hline \multirow{4}{*}{ 2. Kereszt-rét } & 2019. nyár & \multirow{4}{*}{12,94} & 8,31 \\
\hline & 2019. ôsz & & 6,49 \\
\hline & 2019-2020. tél & & 5,86 \\
\hline & 2020. tavasz & & 7,61 \\
\hline \multirow{4}{*}{$\begin{array}{l}\text { 3. Göte-oldal/Kor- } \\
\text { ma föle }\end{array}$} & 2019. nyár & \multirow{4}{*}{39,52} & 23,28 \\
\hline & 2019. ôsz & & 18,68 \\
\hline & 2019-2020. tél & & 16,90 \\
\hline & 2020. tavasz & & 16,06 \\
\hline
\end{tabular}

használt mértékegységre $0,15 \mathrm{~kg} /$ $\left(\mathrm{dm}^{2}\right.$ év). Az évszakos eredmények összesítésével meghatároztuk a talajpusztulás éves mértékét is a vizsgált idôszakra (6. ábra). A térképeken a piros árnyalataival jelölt területeken a talajpusztulás mértéke meghaladja a szakirodalom által elfogadható menynyiséget. Mindegyik mintaterületre jellemző, hogy ezek a kiemelten veszélyeztetett területek az utak mentén, illetve a vízlefolyásoknál találhatók. Az 1. mintaterületen a legmagasabb értékek nem a szôlố területen figyelhetôk meg, hanem a két szélén található szántóföldi részeken. A 2. területen, a területet átszelô ÉÉNy-DDK-i csapású út közepe táján az útra DK-felôl betorkolló idôszakos vízfolyás jelent kiemelten veszélyeztetett területet, ami az út mentén a növényzet hiánya miatt még hangsúlyosabb. A 3. területen az északnyugati Lófingató, és a középtájon található Göte Chardonnay parcellákban figyelhetôk meg magasabb értékek. Ezeken a területeken a szôlôtôkéket a lejtôvel megegyezô irányba telepítették. A teraszos részen (nyugati oldal felsố harmadánál) a legmagasabb értékek a teraszok rézsúje mentén találhatók. A délnyugati rész ezen a területen is szántóföldi múvelés alatt állt.

\subsection{A talajfedés hatása az erózió mértékére}

A talajfedés hatását a forgatókönyv szerint elôállított C-faktor értékekkel mértük fel. Ezzel az új C-faktorral becsült évszakonkénti talajpusztulás egy-egy kivágata a 2. és 3. mintaterületrôl a 8. táblázat térképein láthatók.

A modellek eredményeit összehasonlítva a felmérésen alapuló térképekkel megállapítható, hogy mennyi talaj védhetố meg a lepusztulástól cellánként a füvesítéssel. Mivel az 1. terület esetében nagyon kevés gyepes terület volt az eredeti állapot szerint is, itt

7. táblázat. A mintaterületekre vonatkozó talajpusztulás évszakonkénti összege és az egy négyzetdeciméterre (cellára) jutó átlagértéke kg-ban.

\begin{tabular}{|c|c|c|c|}
\hline Mintaterület & Idôszak & {$\left[\begin{array}{c}\text { Talajpusztulás } \\
{\left[\frac{\mathrm{kg}}{\text { mintaterület } \cdot \text { évszak }}\right.}\end{array}\right]$} & $\begin{array}{l}\text { Átlagos talajpusztulás } \\
\qquad\left[\frac{\mathrm{kg}}{d m^{2} \cdot \dot{v} v s z a k}\right]\end{array}$ \\
\hline \multirow{4}{*}{ 1. Elö-haraszt } & 2019. nyár & 103859,63 & 0,0949 \\
\hline & 2019. ôsz & 11879,41 & 0,0109 \\
\hline & 2019-2020. tél & 9900,02 & 0,009 \\
\hline & 2020. tavasz & 13350,12 & 0,0122 \\
\hline \multirow{4}{*}{ 2. Kereszt-rét } & 2019. nyár & 87939,25 & 0,068 \\
\hline & 2019. ôsz & 9568,85 & 0,0074 \\
\hline & 2019-2020. tél & 8432,08 & 0,0065 \\
\hline & 2020. tavasz & 6365,22 & 0,0049 \\
\hline \multirow{4}{*}{$\begin{array}{l}\text { 3. Göte-oldal/ } \\
\text { Korma föle }\end{array}$} & 2019. nyár & 647561,67 & 0,1639 \\
\hline & 2019. ôsz & 61756,76 & 0,0155 \\
\hline & 2019-2020. tél & 65165,59 & 0,0165 \\
\hline & 2020. tavasz & 71339,35 & 0,0181 \\
\hline
\end{tabular}


Takáts Tünde - Albert Gáspár: Szólóterületek eróziójának térbeli modellezése felszínközeli távérzékelés segítségével

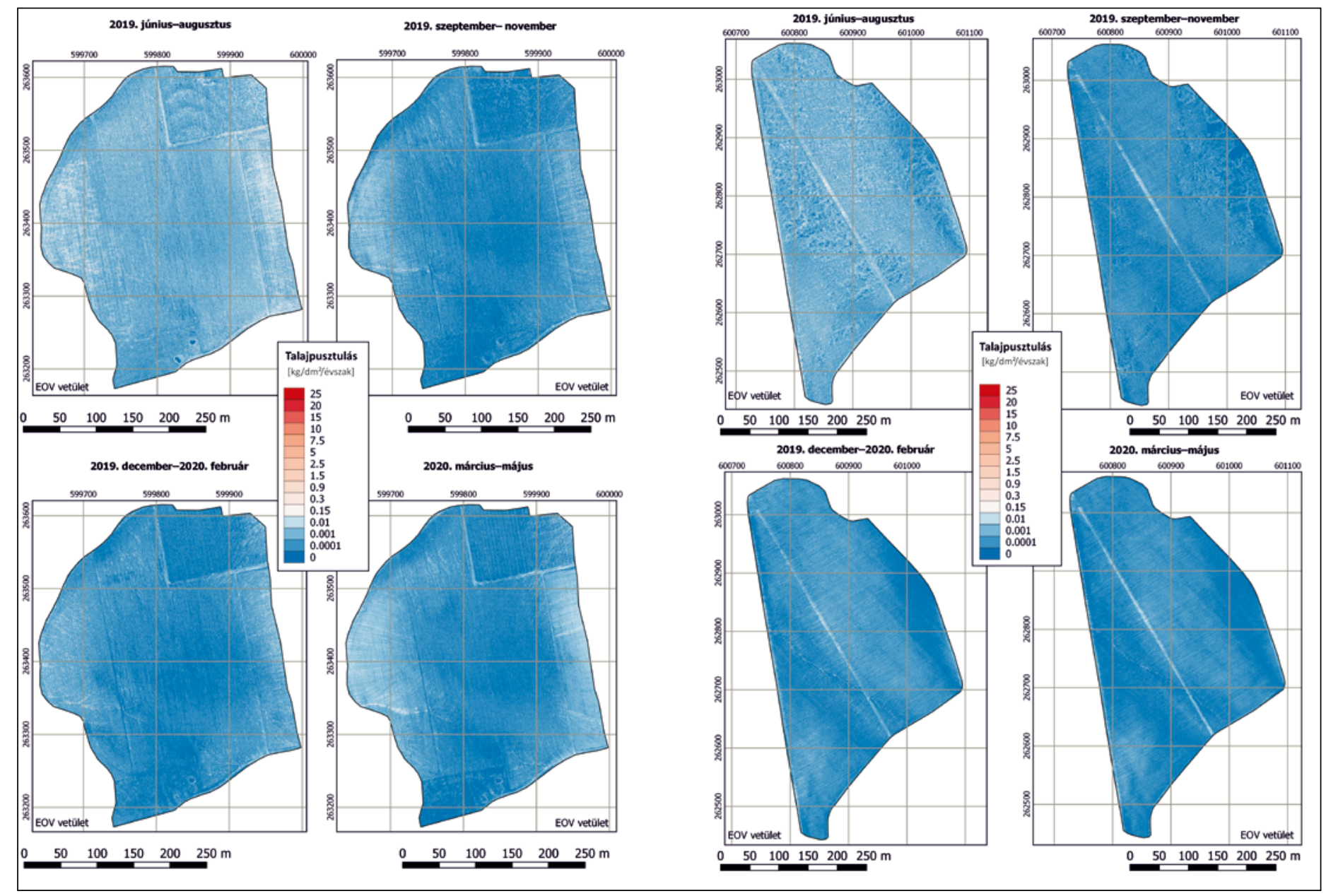

5. ábra. A talajpusztulás becsült értéke évszakonként az 1. és a 2. mintaterületen $\left[\frac{\mathrm{kg}}{\mathrm{dm^{2 } \cdot e ́ v s z a k}}\right]$-ben meghatározva.

8. táblázat. A 2. mintaterület egy-egy kiemelt részének az évszakonkénti talajpusztulás mért és modellezett eredményei térképeken

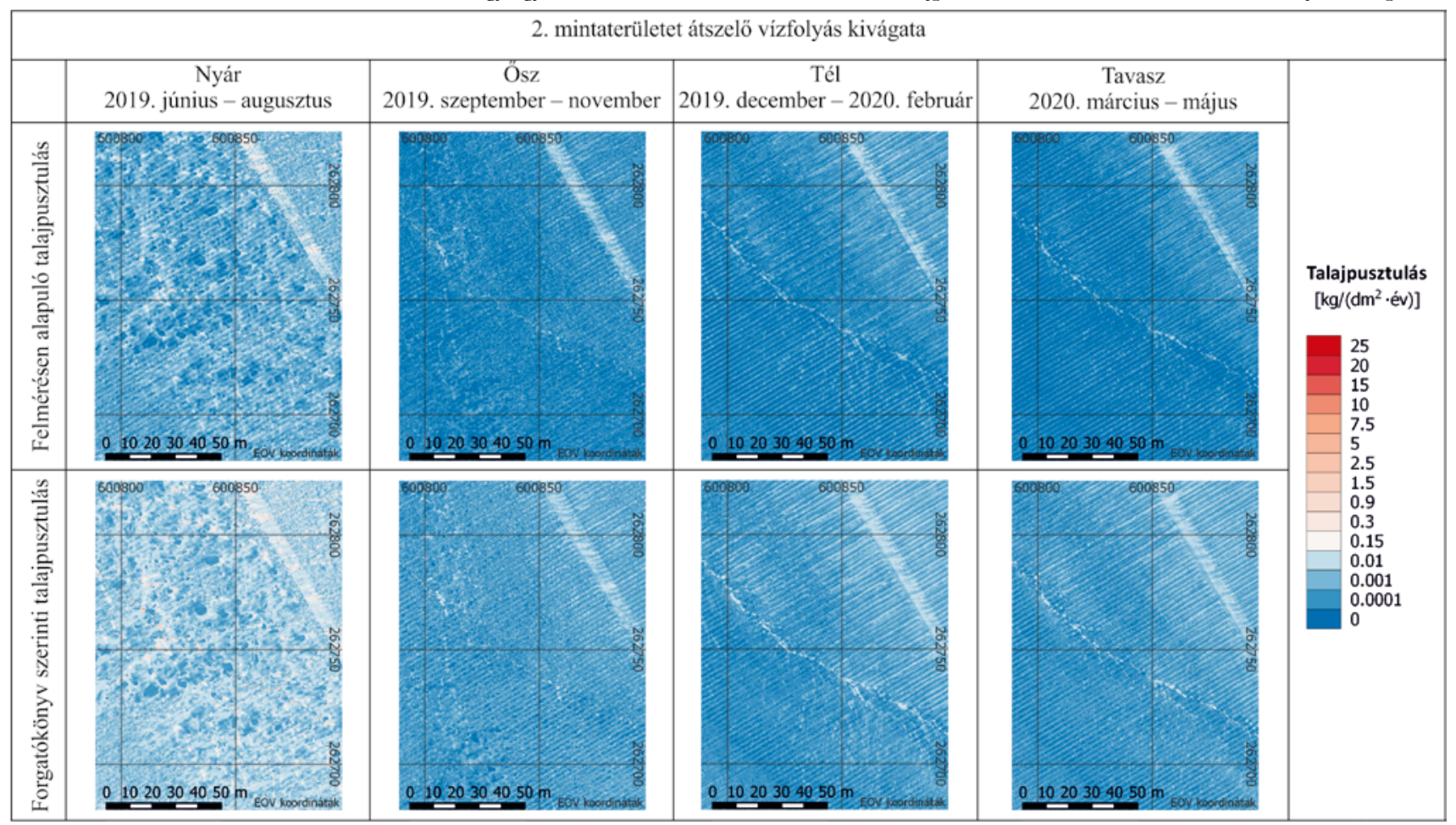


Takáts Tünde - Albert Gáspár: Szólooterületek eróziójának térbeli modellezése felszinközeli távérzékelés segítségével

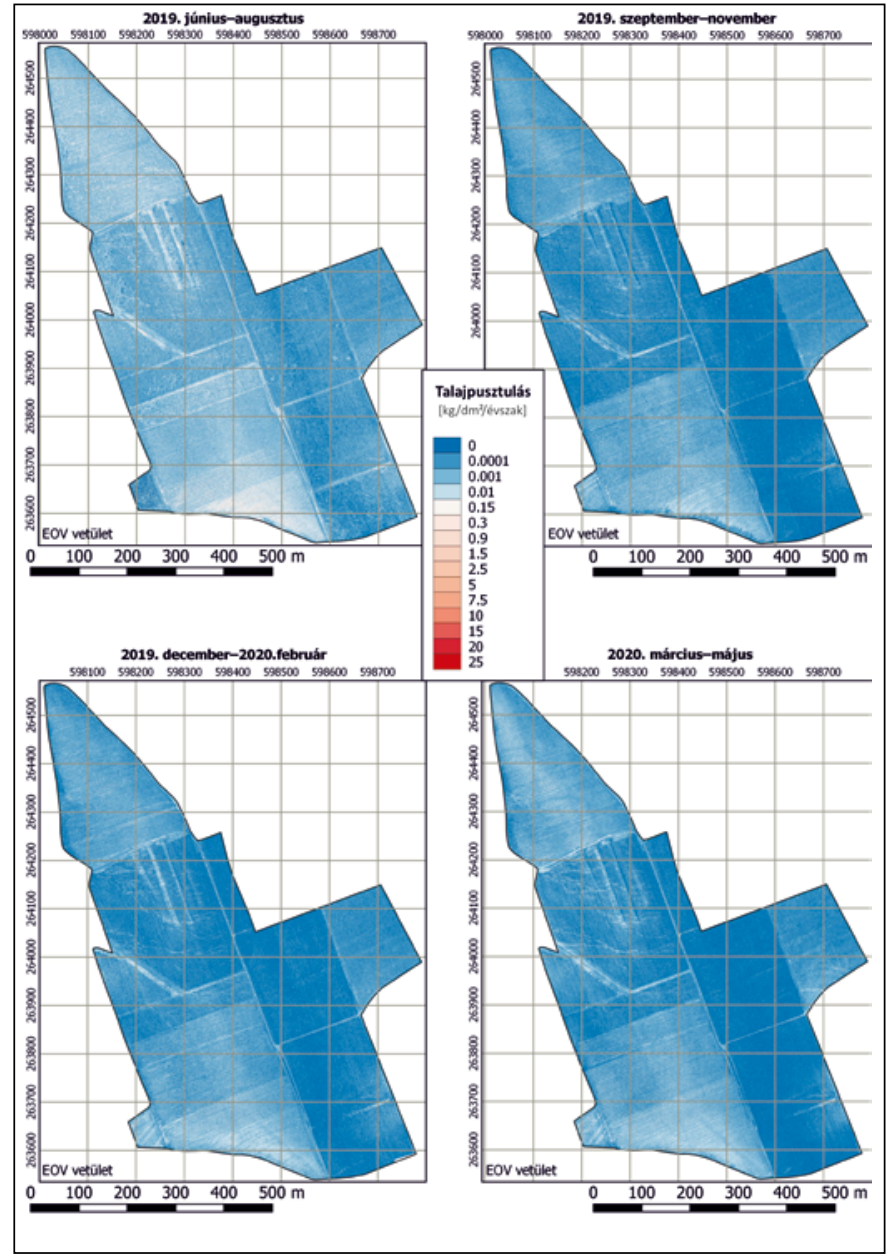

5. ábra. A talajpusztulás becsült értéke évszakonként a 3. mintaterületen $\left[\frac{\mathrm{kg}}{\mathrm{dm^{2 } \cdot e ́ v s z a k}}\right]$-ben meghatározva.

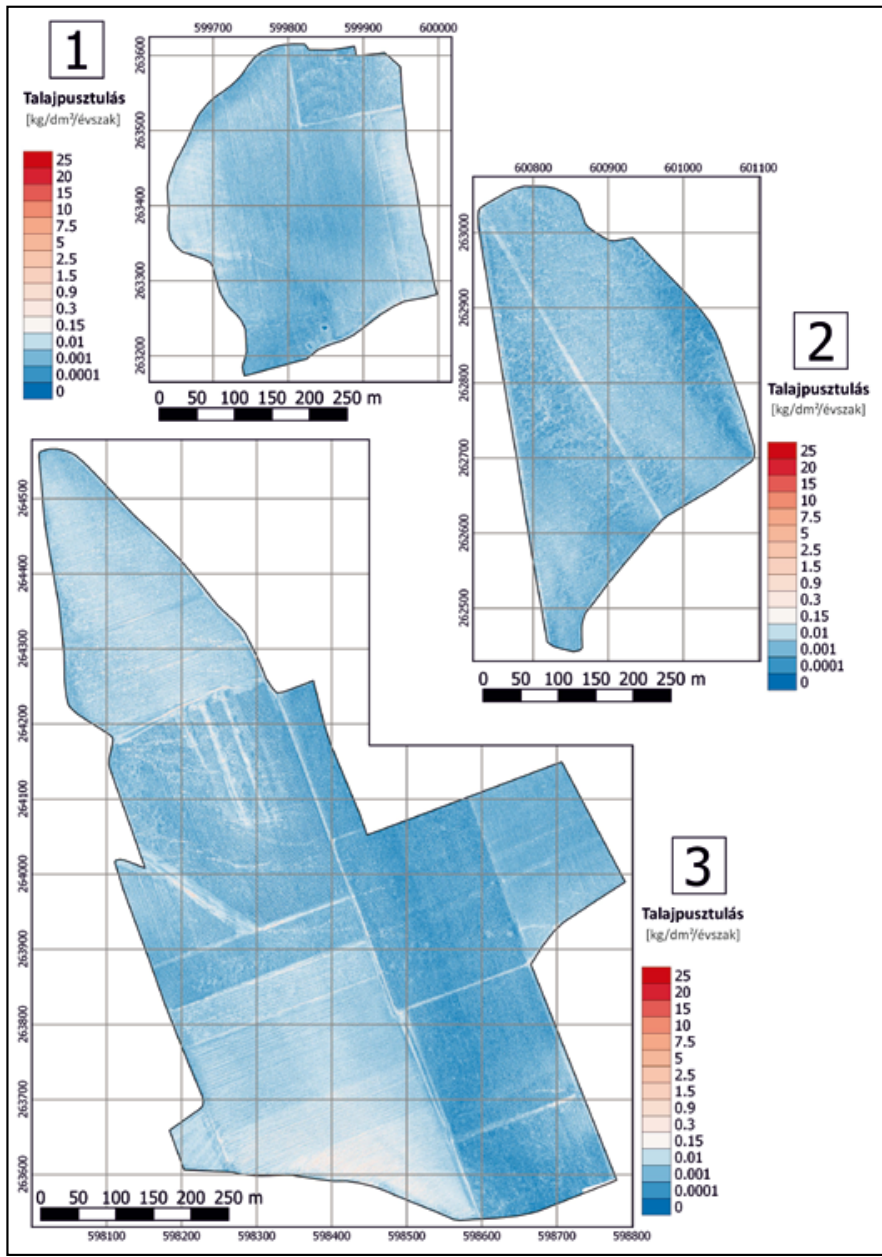

6. ábra. A becsült éves talajpusztulás az egyes mintaterületeken $\left[\frac{k g}{d m^{2} \cdot e ́ v s z a k}\right]$-ben meghatározva.

8. táblázat. A 3. mintaterület egy-egy kiemelt részének az évszakonkénti talajpusztulás mért és modellezett eredményei térképeken

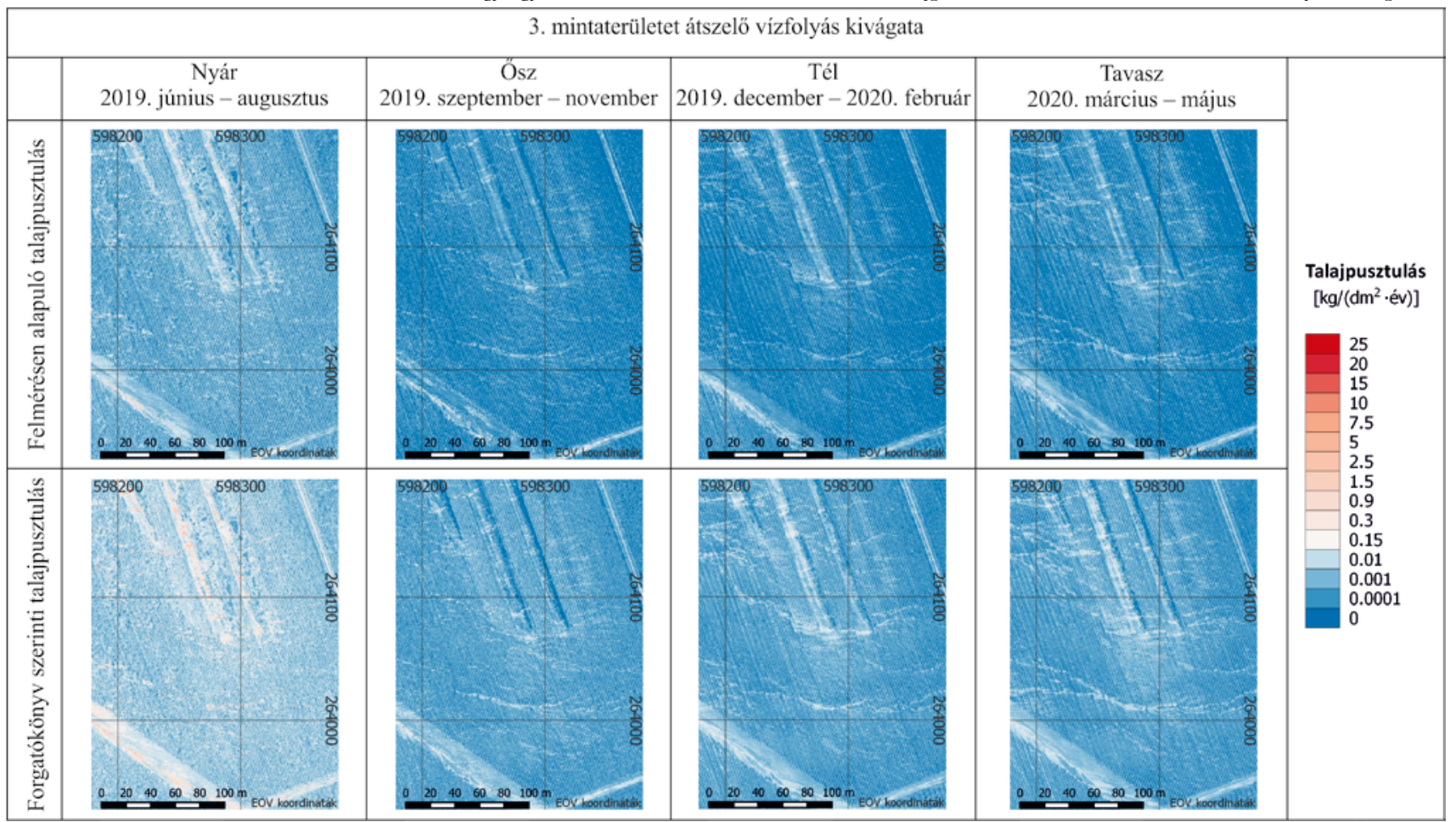


9. táblázat. Felmérésen alapuló és modellezett talajpusztulás mértéke az egyes mintaterületeken

\begin{tabular}{|c|c|c|c|c|c|}
\hline \multicolumn{7}{|c|}{ Talajpusztulás mértéke $\left[\frac{\mathrm{k} k}{\text { mintaterület ·évszak }}\right]$} \\
\hline \multicolumn{7}{|c|}{ Mintaterület } & Nyár & \multicolumn{1}{c|}{ Osz } & \multicolumn{1}{c|}{ Tél } & \multicolumn{1}{c|}{ Tavasz } \\
\hline \multirow{2}{*}{1.} & Felmérésen alapuló & 103859,63 & 11879,41 & 9900,02 & 13350,12 \\
\cline { 2 - 6 } & Forgatókönyv szerinti & 122851,36 & 17549,72 & 12667,99 & 14374,29 \\
\hline \multirow{2}{*}{2.} & Felmérésen alapuló & 87939,25 & 9568,85 & 8432,08 & 6365,21 \\
\cline { 2 - 6 } & Forgatókönyv szerinti & 358282,54 & 24347,06 & 21388,16 & 20013,91 \\
\hline \multirow{2}{*}{3.} & Felmérésen alapuló & 647561,67 & 61074,50 & 65165,59 & 71339,35 \\
\cline { 2 - 6 } & Forgatókönyv szerinti & 1976134,52 & 137683,33 & 138353,08 & 121945,28 \\
\hline
\end{tabular}

található a legkisebb eltérés a modell és felmért erózió között. A különbségek elsôsorban a mintaterületre belógó idôsebb szôlôparcella területén találhatók. A másik két mintaterület esetében már jelentôsebb volt a különbség. A 2. terület esetében jelentôs változás van a területet átszeló vízfolyás mentén, míg a 3. terület esetében több kiemelt terület is van: a teraszos parcella; a nagyobb vízfolyások; és azok a parcellák, ahol a lejtőre nem merôleges múvelés zajlik. A mintaterületek évszakos változását a 9. táblázat foglalja össze.

A forgatókönyv szerinti évszakos eredmények összesítésével éves talajpusztulás becslés is született (7. ábra). Az eredmények alapján minden mintaterületen nagyobb lenne a talajpusztulás mértéke, ha nem füvesítenék a sorközöket. A 10. táblázatban a különbözô mintaterületekre vonatkozó valós és a forgatókönyv szerinti éves talajpusztulási-értékek összehasonlítása látható. A számítás a talajerózió cellánkénti értékeinek területenkénti összesítését mutatja. Az 1. mintaterület esetében nem számottevố ez a változás a füvesítés hiánya miatt (1,2-szeres). A kettes és hármas területek esetében ez jóval számottevôbb (3,78 és 2,8-szoros). Az éves talajpusztulás mértékében a legnagyobb változás tehát a 2 . mintaterületen lenne, ahol a teljes területre vonatkozóan mintegy 311,7 tonnával több lenne az erodált talaj.

Mintaterületenként kiszámítottuk az egy $\mathrm{dm}^{2}$-re jutó átlagos talajpusztulás mértékét mind az eredeti, mind pedig a forgatókönyv szerint modellezett értékekkel (8. ábra). A 2. mintaterületen minimum 2,54-szoros és maximum 4,07-szoros, míg a 3. mintaterület esetében minimum 1,71-szoros és maximum 3,05-szoros lenne a talajpusztulás mértéke. A legnagyobb eltérés minden esetben nyári idószakban tapasztalható.
10. táblázat. Az éves talajpusztulás és a modellezett éves talajpusztulás mértéke mintaterületenként.

\begin{tabular}{|l|c|c|}
\hline \multicolumn{1}{|c|}{ Mintaterület } & $\begin{array}{c}\text { Éves talajpusztulás } \\
{\left[\frac{\mathrm{kg}}{\text { mintaterület } \cdot \dot{v} v}\right]}\end{array}$ & $\begin{array}{c}\text { Forgatókönyv szerinti } \\
\text { éves talajpusztulás } \\
{\left[\frac{\mathrm{kg}}{\text { mintaterület } \cdot \dot{e} v}\right]}\end{array}$ \\
\hline 1. Elö-haraszt & 138989,18 & 167443,36 \\
\hline 2. Kereszt-rét & 112305,39 & 424031,67 \\
\hline 3. Göte-oldal/Korma föle & 845141,11 & 2374116,29 \\
\hline
\end{tabular}

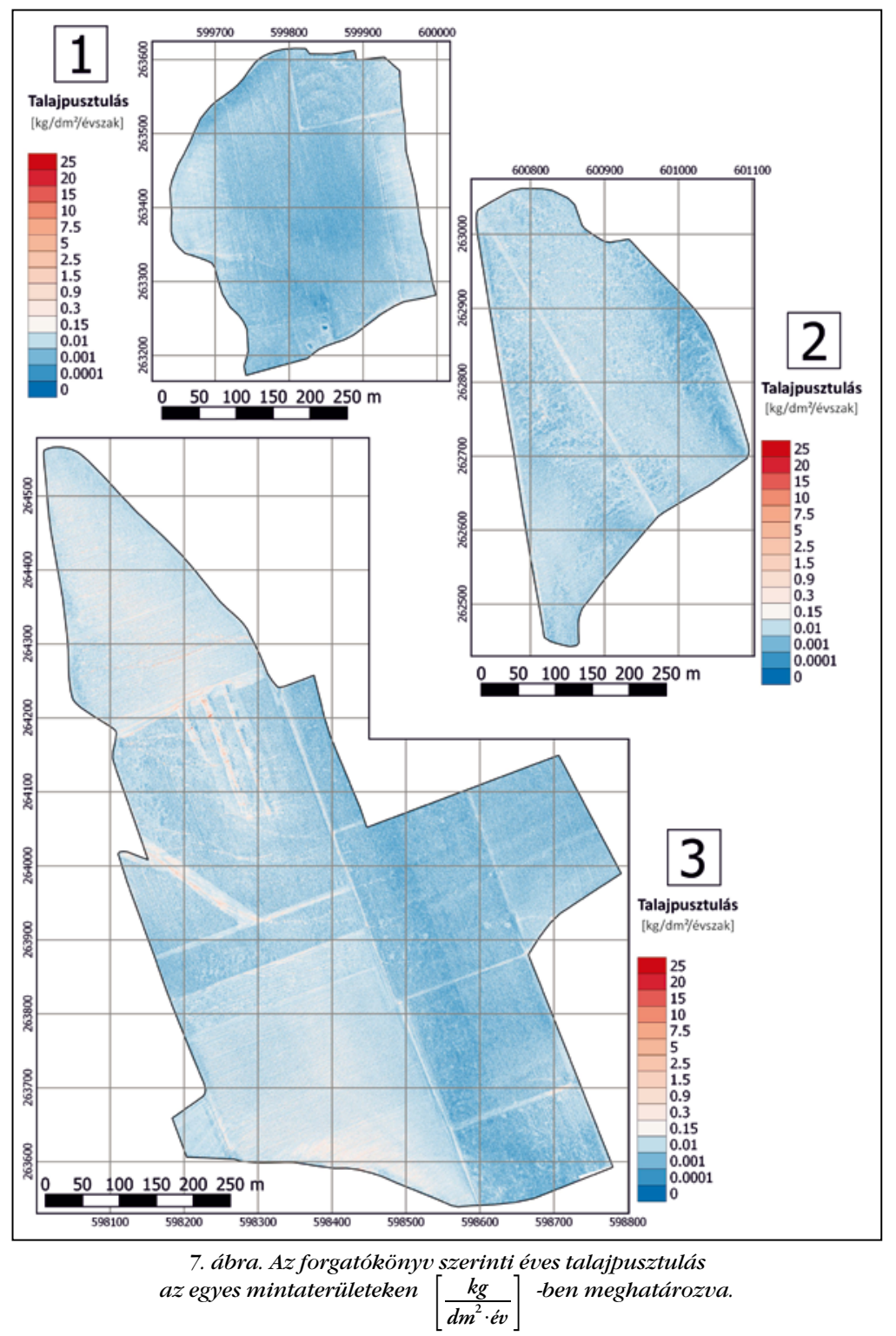




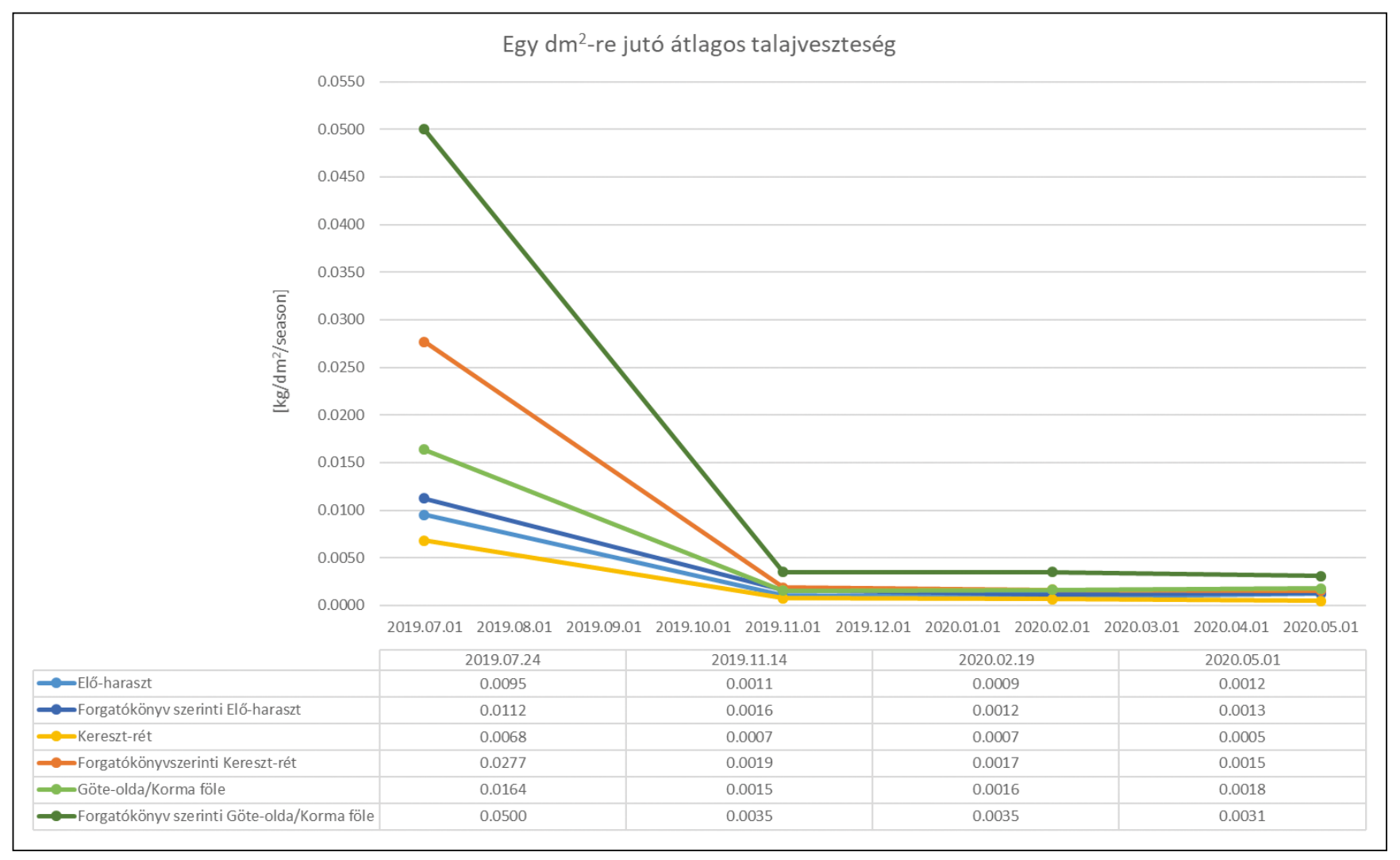

8. ábra. Az egy négyzetdeciméterre jutó átlagos talajpusztulás értékei.

\section{4. Összegzés}

A kutatás a talajerózió ismeretének fontosságára, és mértékének meghatározására irányult kiemelten veszélyeztetett szőlooterületeken a Gerecse északi területén. A kitűzött cél az volt, hogy az egyes mintaterületekrôl nagyfelbontású talajpusztulási térképek készüljenek, melyek segítségül szolgálhatnak a szólészet számára. Összesen három mintaterületen, 63,4 hektáron végeztük a vizsgálatokat Dunaszentmiklós területén. A talajpusztulás megfigyelését évszakos idôskálán végeztük, így az erózió éven belüli változása is tanulmányozható volt.

A kutatómunka során a nagyfelbontású adatok (10cm/pixel) elóállítására UAV-eszköz felvételeit használtuk fel. A talajpusztulás becslésére az USLEegyenletet alkalmaztuk. Az LS-, C-, Pés R-faktorok térképei saját felmérések alapján készültek. Az UAV által készített képek segítségével határoztuk meg az LS értékeket, mely a lejtố hosszának és meredekségének a hatását mutatja meg, a C értékeket, mely a különböző növényborítottság befolyásoló mértékét mutatja meg és a P-faktort, mely az alkalmazott talajmúvelési mód hatását vizsgálja. Az R-faktor meghatározása a terület közelében található két meteorológiai állomás adataiból történt. A K faktorra vonatkozó térbeli állományt a Talajtani Intézet bocsátotta rendelkezésre.

Az egyes mintaterületekre elvégeztük a talajpusztulás évszakos, valamint az egész évre vonatkozó mértékének számítását. Elkészült egy modell is, melyben a tôkesorok közötti gyepesítés hatását vizsgáltuk.

Az eredményekből megfigyelhetô, hogy a mintaterületeken hogyan változott a talajpusztulás a különbözó évszakokban. A legnagyobb talajpusztulás minden esetben a nyári idôszakban volt. Ekkor az erózió mértéke kb. egy nagyságrenddel eltért a többi időszakétól. Ezzel szemben, az ôszi és a téli idôszakban nem tapasztalható nagymértékú eltérés. A 2020. tavaszi időszakában nem volt jelentôs csapadék, így az erózió becslése során a téli és az ôszi idôszakhoz hasonló értékeket tapasztaltunk. Az R értékeket és a csapadék adatokat összehasonlítva elmondható, hogy nyáron az intenzív, míg a többi évszakban a lassú hosszabb ideig tartó esốzés volt jellemzô. Ez az évszakos változás nemcsak a csapadék hatásában mutatkozik meg, hanem a növényborítottság változásában is. Az alkalmazott talajmúvelési mód jelentôsége is megjelenik az eredményekben. Azokon a területeken, ahol a lejtôvel megegyezô irányban telepítették a tôkéket, ott nagyobb a talajerózió. A modellezés során, a gyepesítés fontosságára is számszerú eredményeket kaptunk. A gyepesítés jelentôsége a 2. és a 3. mintaterület esetében mutatkozik meg. A 2. mintaterületen minimum 2,54-szoros és maximum 4,07-szoros, míg a 3. mintaterület esetében minimum 1,71-szoros és maximum 3,05szoros lenne a talajpusztulás mértéke, ha csupaszon hagynák a talajt. A kutatás eredményei alapján tehát egyértelmúen javasolható a sorok közötti füvesítés az eróziócsökkentés érdekében. A tanulmányban bemutatott precíziós módszerekkel végzett eróziótérképezés hozzájárulhat a szôlészetek a fenntartható gazdálkodás érdekében végzett munkájához.

\section{Köszönetnyilvánítás}

Kutatásunkat a Nemzeti Kutatási Fejlesztési és Innovációs Alap Tématerületi kiválósági programja 
(ED_18-1-2019-0030 és TKP2020NKA-06), és az Információs és Technológiai Minisztérium ÚNKP19-2 kódszámú Új Nemzeti Kiválóság Programja támogatta. Köszönjük a Hilltop Neszmély Zrt. munkatársainak, hogy engedélyezték és segítették a kutatási munkánkat, az ELKH ATK TAKI munkatársainak a közremúködést a drónok reptetésében, valamint az Országos Meteorológiai Szolgálatnak a felhasznált csapadék adatokat.

\section{Irodalom}

Albert, G. 2013. A kőpatak völgye. Természet Világa, 144(2), old:: 85-86.

Brychta,J., - Brychtová, M. 2020. Possibilities of including surface runoff barriers in the slop-length factorcalculation in the GIS environment and its integration in the user-friendly LS-RUSLE tool. Soil and Water Research, 15(4), pp. 246-257.

Chidi, C. L. - Zhao, W. - Chaudhary, S. - Xiong, D. - Wu, Y. 2021. Sensitivity Assessment of Spatial Resolution Difference in DEM for Soil Erosion Estimation Based on UAV Observations: An Experiment on Agriculture Terraces in the Middle Hill of Nepal. ISPRS International Journal of Geo-Information, 10(1), 28.

Conforti, M. - Buttafuocoa, G. - Ragob, V. - Aucellic, P. - Robustellib, G. Scarciglia, F. 2015. Soil loss assessment in the Turbolo catchment (Calabria, Italy). Journal of Maps, 815-825. DOI: $10.1080 / 17445647.2015 .1077168$

Dezsố , J. - Lóczy , D. - Rezsek, M. - Hüppi , R. - Werner, J. - Horváth, L. 2020. Crop growth, carbon sequestration and soil erosion in an organic vineyard of the Villány Wine District, Southwest Hungary. Hungarian Geographical Bulletin, 69(3), pp. 281-298. DOI: 10.15201/hungeobull.69.3.4

Fantappiè, M. - Priori, S. - Costantini, E. 2014. Soil erosion risk, Sicilian Region (1:250,000 scale).Journal of Maps, 11(2), pp. 323-341.

Fehér, F. - Horváth, J. - Ondruss, L. 1986. Területi vízrendezés. Budapest: Múszaki Könyvkiadó.

Fernández, T. - Pérez-García, J. L. - GómezLópez, J. M. - Cardenal, J. - Calero, J. Sánchez-Gómez, M. - Delgado, J. - TovarPescador, J. 2020. Multitemporal Analysis of Gully Erosion in Olive Groves by Means of Digital Elevation Models Obtained with Aerial Photogrammetric and LiDAR Data. ISPRS International Journal of Geo-Information, 9(4), p. 260.

Foster, G. R. - McCool, D. K. - Renard, K. G. - Moldenhauer, W. C. 1981. Conversion of the universal soil loss equation to SI metric units. Journal of Soil and Water Conservation, 36(6), pp. 355-359.

Gerzsenyi, D. - Albert, G. 2017. Landslide susceptibilit estimations in the Gerecse hills (Hungary). In EGU General Assembly Conference Abstracts (19), p: 4146.

Gerzsenyi, D., - Albert, G. 2021. Landslide inventory validation and susceptibility mapping in the Gerecse Hills, Hungary. Geo-spatial Information Science, 1-11. DOI: $10.1080 / 10095020.2020 .1870872$

Kis, É. - Balogh, J. 2013. A Gerecse felszínmozgásos területei. In É. Kis, Terresztikus domborzatfejlôdés a Vértes és a Gerecse környezetében a bérbaltaváriumtól a holocénig (pp. 121-137.). Budapest: Magyar Tudományos Akadémia- Csillagászati és Földtudomyányi Kutatóközpont

Lahloi, H. - Rhinane, H. - Hilali, A. - Lahssini, S. - Khalile, L. 2015. Potential erosion risk calculation using remote sensing and GIS in Oued El Maleh Watershed, Morocco. Journal of Geographic Information System, 7, pp. 128-139. DOI: 10.4236/jgis.2015.72012

Meinen, B. U. - Robinson, D. T. 2021. Agricultural erosion modelling. Evaluating USLE and WEPP field-scale erosion estimates using UAV timeseries data. Environmental Modelling $\mathcal{E}$ Software, 137, 104962.

Odongo, V. - Onyando, J. - Mutua, B. van Oel, P. - Becht, R. 2013. Sensitivity analysis and calibration of the Modified Universal Soil Loss Equation (MUSLE) for the upper Malewa Catchment, Kenya. International Journal of Sediment Research, 28(3), pp. 368-383.

Panagos, P. - Borrelli, P. - Meusburger, K. - Alewell, C. -Lugato, E. - Montanarella L. 2015. Estimating the soil erosion covermanagement factor at the European scale. Land Use Policy, 48, pp. 38-50.

Panagos, P. - Borrelli, P. - Meusburger, K. - van der Zanden, E. H. - Poesen, J - Alewell, C. 2015. Modelling the effect of support practices (P-factor) on the reduction of soil erosion by water at European scale. Environmental Science E Policy, 51, pp. 23-34.

Pásztor, L. - Waltner, I. - Centeri, C. Belényesi, M. - Takács, K. 2016. Soil erosion of Hungary assessed by spatially explicit modelling. Journal of Maps 1-8.

Pijl, A. - Reuter, L. E. - Quarella, E. - Teun, V. A. - Tarolli, P. 2020. GIS-based soil erosion modelling under various steepslope vineyard practices. 193, 104604. DOI: 10.1016/j.catena.2020.104604

Presbitero, A. L. 2013. Soil erosion studies on steep slopes of humid-tropic Philippines. Queensland. Australia: School of Environmental Studies, Nathan Campus, Griffith University.

Rakonczás, N. 2014. Szôlốtermesztés. Debreceni Egyetemi Kiadó.

Ruszkiczay-Rüdiger, Z. - Fodor, L. Csillag, G. - Braucher, R. -Kele, S. Novothny, Á., Thamó-Bozsó, E. - Virág, A. - Molnár, G. - Madarász, B. - Team, A. 2016. Spatially and temporally varying Quaternary uplift rates of the Gerecse Hills, Northern Pannonian Basin, using dated geomorphological horizons in the Danube valley. In EGU General Assembly Conference Abstracts (18), p. 6463.
Schweitzer, F. 1989. Surface movements of the Gerecse Mountain's northern part. In J. Galamos, Selected environmental studies (pp. 34-35.). Budapest: Geographical Research Institute, Hungarian Academy of Sciences.

Stefanovits, P. 1992. Talajtan. Budapest: Mezógazda Kiadó.

Szendrei, G. 1998. XII. Talajpusztulás. In Talajtan (pp. 235-241.). Budapest: ELTE Eötvös Kiadó.

Takáts, T. 2018. Talajerózió és üledékfelhalmozódás térképezése távérzékelési adatok alapján, Szakdolgozat. Budapest.

Takáts, T. 2020. Talajerózió vizsgálata egy hegylábi mezôgazdasági területen a Gerecse térségében, TDK dolgozat. Budapest.

Waltner, I. 2018. Eróziós potenciál becslése távérzékeléssel. In G. Áldorfai , \& T. Tóth (Szerk.), SZIE kiváló tehetségei" konferencia elóadásainak összefoglaló kiadványa (p. 136). Gödöllő, Magyarország: Szent István Egyetemi Kiadó.

Waltner, I. - Pásztor, L. - Centeri, C. - Takács, K. - Pirkó, B. - Koós, S. - László, P. 2018. Evaluating the new soil erosion map of Hungary-A semiquantitative approach. Land Degradation Development, 29, 1295-1302. DOI: $10.1002 / 1 \mathrm{dr} .2916$

Waltner, I. - Saeidi, S. - Grósz, J. - Centeri, C. - Laborczi, A. - Pásztor, L. 2020. Spatial Assessment of the Effects of Land Cover Change on Soil Erosion in Hungary from 1990 to 2018. ISPRS International Journal of Geo-Information, 11, 667. DOI: $10.3390 /$ ijgi9110667

Wischmeier, W. H. - Smith, D. D. 1978. Predicting rainfall erosion lossesa guide to conservation planning. USA: USDA, Science and Education Administration.

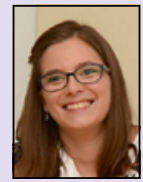

Takáts Tünde doktorandusz

ELTE Természettudományi Kar, Földtudományi Doktori Iskola ELKH Agrártudományi Kutatóközpont Talajtani Intézet tunde.takats@gmail.com

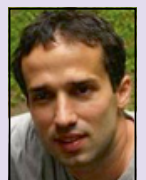

Dr. Albert Gáspár egyetemi docens

ELTE IK Térképtudományi és Geoinformatikai Intézet albert@ludens.elte.hu 